it abounds in elementary errors as regards facts, botanical and mechanical. For example, the account of the production of wood by cambium is truly fantastic, while the implication is made that when dead wood is absorbing water and swelling, the cells of the medullary rays exert great pressure by reason of their turgidity. But quite inexcusable are misquotations of various scientific workers, including $\mathrm{R}$. Hartig and Mathieu (who is made responsible for the statement that heartwood and sapwood are synonymous " expressions").

Errors as regards matters of fact are matched by the author's methods of reasoning and the conclusions that he draws. According to him the wood-vessels cannot have very important functions, " inasmuch as Conifers do without them." Or, again, he writes of a beam under transverse bending load that "the height may be reduced and yet the beam be stronger" ; and in dealing with mechanical tests he not only "hopes and believes" that practical men do not "pay any attention to the figures so far supplied by physicists," but also advises the abolition of "all calculations whatsoever." A number of excellent photographs of woodstructure impart some value to the book.

\section{Textile Design and Colour: Elementary Weaves and} Figured Fabrics. By W. Watson. Second edition, with an Appendix on Standard Yarns, Weaves, and Fabrics. Pp. xi +436 . (London: Longmans, Green and Co., I92I.) 2 Is. net.

THE comprehensiveness of Mr. Watson's training is reflected from the pages of this book. A student in the Textile Industries departments of the University of Leeds and the Bradford Technical College, and successively head of the Textile Departments at Salford and the Royal Technical College, Glasgow, Mr. Watson has naturally produced a volume which is both broad in outlook and sequential in treatment. In the maze of small weave. effects, for example, it is so easy to degenerate into mere statement and illustration that any writer who can introduce a sequential and reasonable treatment leading to that imaginative insight, which is so much to be desired in the cloth constructor, is to be congratulated. In the future probably more conventional scientific treatment of the structures here referred to will be necessary, for not only do surh matters as combinations and permutations appear, but, as was quite accidentally discovered at the meeting of the Mathematical Association last year, the problem of sateen cloth structure is the problem of atomic grouping in crystal structure.

Mr. Watson's treatment of the colour problems involved in textile designing is by no means so satisfactory: it largely resolves itself into "colour and weave" form. The technical treatment of figured fabrics is excellent, and the appendix upon Standard Fabric should prove very useful to all designers and manufacturers.

A. F. B.

Principia Ethica. By Dr. George Edward Moore. Pp. xxvii +232. (Cambridge: At the University Press, 1922.) I5s. net.

THIs volume is the reprint of the famous and muchdiscussed treatise of Dr. G. E. Moore, the present Editor of Mind, which was first published in 1903: Readers will turn at once with interest to the brief note added to the preface in which the author tells us that he is still in agreement with its main tendency and conclusions. His thesis is that "good" is indefinable, but that "the good" can be defined. The good is the thing, simple or complex to any degree, to which the indefinable predicate good belongs. He illustrates his meaning by an extreme case. He asks us to imagine a world exceedingly beautiful, and then to imagine the ugliest world it is possible to conceive. We are asked, in comparing these worlds, to accept the limitation that "we are not entitled to imagine that any human being ever has, or ever, by any possibility, can, live in either." Is it irrational, he asks, to hold that it is better that the one should exist and not the other? To most students of ethics the limitation makes the question nonsense in the literal meaning of the term. It is interesting to find that Dr. Moore can still think it a rational question after the lapse of twenty years. Yet we must admit the force of his logic, for if value is to have any meaning at all to the realist, it can only be by finding some way of attaching it to the object and presenting it in complete abstraction from the subject, for the mind is limited in its activity to contemplation.

Rocks and Fossils and How to Identify Them. By J. H. Crabtree. Pp. 63. (London: The Epworth Press ; J. Alfred Sharp, n.d.) Is. gd. net.

WE have here a book, very prettily illustrated by photographs; but the text is not in keeping with the author's daring statement that "geology is, of all concrete science studies, most exact in its observations and conclusions." The loss of land at Dunwich (p. I4) should not be ascribed to subsidence; faults (p. I8) do not imply that "the two parts are pitched at different angles " ; limestones are said to be " generally combined with mineral matter"; Radiolaria are photographed in one of the admirable plates as "flinty shell remains of foraminifera"; and in another plate a very mixed assemblage of fossils, including halysites and Fenestella, is attributed to the Old Red Sandstone. "Interlocking teeth" are given as a characteristic of Labyrinthodon, and Tyrannosaurus is said to have preyed upon the mammoth. We must not dilate on the reappearance of Eozoon and the "Laurentian system," or on the "boreal climate" of the Trias (p. 56). If we interpret his remarks on "sauroid fishes" as referring to Sauripterus, the author has been diligent in his reading, and we must regret that he has shown so little regard for exactitude in "observations and conclusions." G. A. J. C.

The Mineral Resources of Burma. By N. M. Penzer. (Federation of British Industries: Intelligence Department.) Pp. viii + I76. (London: G. Routledge and Sons, Ltd.; New York: E. P. Dutton and Co., I922.) 3is. $6 d$. net.

Mr. Penzer, on behalf of the Federation of British Industries, has undertaken with conspicuous success the task of summarising the information hitherto inconveniently scattered through various unrelated publications concerning the mineral resources of the province of Burma. He has taken care to secure the co-operation of recognised authorities with special 